\title{
Antibiotic-Impregnated Polymethylmethacrylate as an Anterior Biomechanical Device for the Treatment of Cervical Discitis and Vertebral Osteomyelitis: Technical Report of Two Cases
}

\author{
Servikal Diskitis ve Vertebral Osteomiyelit Tedavisinde Bir Anterior \\ Biyomekanik Cihaz Olarak Antibiyotik Emdirilmiş Polimetilmetakrilat: \\ İki Olgunun Teknik Raporu
}

Ryan J. BARRETT ${ }^{1,2}$, Lee SANDQUIST ${ }^{1}$, Boyd F. RICHARDS ${ }^{1,2}$, Teck M. SOO ${ }^{1,2}$

${ }_{1}^{1}$ Providence Hospital and Medical Centers, Department of Neurological Surgery, Southfield, MI, USA

${ }^{2}$ Michigan Spine and Brain Surgeons, Southfield, MI, USA

Corresponding Author: Lee SANDQUIST / E-mail: sandq1@hotmail.com

\begin{abstract}
AIM: To evaluate the feasibility of this novel surgical approach for treatment of cervical discitis and vertebral osteomyelitis.

MATERIAL and METHODS: This is a report of two patients who underwent anterior cervical decompression for discitis and vertebral osteomyelitis (DVO) with cervical spine reconstruction with polymethylmethacrylate impregnated with antibiotics (AI-PMMA).

RESULTS: Both patients had successful procedures that were followed by 6 weeks of intravenous antibiotics. Stabilization and eradication of infection was achieved with clinical and radiographic stabilization seen in both. Follow-up is greater than 18 months and both patients remain off antibiotics.

CONCLUSION: The described technique using AI-PMMA offers immediate structural stability and local delivery of high concentration of antibiotics. Use in two patients has demonstrated a cost effective, long-term biomechanically stable construct and infection control.

KEYWORDS: Polymethylmethacrylate, Antibiotic, Cervical discitis, Cervical osteomyelitis, Anterior biomechanical device

ÖZ

AMAÇ: Servikal diskit ve vertebral osteomiyelit tedavisi için yeni bir cerrahi yaklaşımın uygulanabilirliğini değerlendirmek.

YÖNTEM VE GEREÇLER: Bu rapor DVO için antibiyotik emdirilmiş polimetilmetakrilat (AI-PMMA) ile servikal vertebra rekonstrüksiyonu ile anterior servikal dekompresyon uygulanan iki hastayla ilgilidir.

BULGULAR: Her iki hasta başarılı bir ameliyat geçirdi ve intravenöz antibiyotik ile 6 hafta takip edildi. Enfeksiyon stabilizasyonu ve eradikasyonu ile birlikte klinik ve radyografik stabilizasyon iki hastada da sağlandı. Takip 18 ayı geçmiştir ve şu anda iki hasta da antibiyotik kullanmamaktadır. SONUÇ: Tarif edilen Al-PMMA tekniği, hızlı yapısal stabilite ve yüksek bir antibiyotik konsantrasyonunun lokal iletimini sağlar. İki hastada maliyet etkinlik, uzun vadeli biyomekanik istikrarlı yapı ve enfeksiyon kontrolü elde edilmiştir.
\end{abstract}

ANAHTAR SÖZCÜKLER: Polimetilmetakrilat, Antibiyotik, Servikal diskitis, Servikal osteomiyelit, Anterior biyomekanik cihaz

\section{INTRODUCTION}

The treatment of discitis and vertebral osteomyelitis (DVO) remains a challenge. Options range from conservative management, including bracing and antibiotics, to aggressive debridement and primary reconstruction $(1,11,13,24)$. Although gaining wider acceptance and support in the literature, the use of structural allografts and instrumentation in DVO remains controversial $(1,18,22)$. This is primarily based on the perceived risk of persistent infection related to a devitalized graft and adjunctive use of spinal implants that in turn raises concerns of construct failure. The use of antibiotic-impregnated polymethylmethacrylate (AI-PMMA) has long been used in the orthopedic community for the treatment of osteomyelitis outside of the spine, specifically in infected joints and long bones $(8,12,16,25)$. A biomechanical device that offers immediate stability and the local delivery of antibiotics provides an appealing option in the setting of DVO. This communication reports two patients who underwent anterior cervical decompression for DVO followed by reconstruction with polymethylmethacrylate impregnated with antibiotics (AI-PMMA). 


\section{METHODS}

\section{Patients}

Two patients who presented with symptoms of neck pain and worsening neurological status were diagnosed clinically and radiographically with cervical discitis and osteomyelitis (Figures 1-7). Both had known risk factors for the diagnosis: one patient has a history of multiple sclerosis and Crohn's disease for which he received steroid therapy for symptom control; the other had undergone a routine dental procedure three weeks prior to admission. In both patients corpectomies were performed to decompress the spinal cord and remove all visible infected tissue. Initially, the patient on steroid therapy was treated with a multilevel corpectomy with placement of a structural autograft strut obtained from his iliac crest followed by placement of an anterior cervical plate (Figure 2). Seven days post-operatively, the patient developed acute increased neck pain and kyphotic deformity. Cervical spine imaging revealed failure of the surgical construct with anterior displacement of the inferior portion of the graft and plate along with subluxation of the $\mathrm{C} 5-\mathrm{C} 6$ facet (Figure 3). This patient subsequently underwent reconstruction with AlPMMA followed by staged posterior cervical instrumentation.

\section{Surgical Technique}

Microsurgical corpectomies were performed at the diseased levels through a ventral approach. Infected bone and disc were removed along with the posterior longitudinal ligament. Any visualized epidural involvement of the infectious process was evacuated and cultured. The superior and inferior endplates were prepared to ensure an optimal surface to seat the graft. Gelfoam was placed over the dura in an effort to provide a buffer from any exothermic reaction that occurs during the curing process of the graft (21). Steinman pins (Smith \& Nephew, Memphis, TN) were placed rostral and caudal within the vertebral bodies to help secure the cement against any dislodgement. Prior to implantation, PMMA cement (41 grams) was mixed intraoperatively with onegram vancomycin powder and 1.2 grams tobramycin powder. During implantation, Caspar distraction pins (Aesculp, Center Valley, PA) were placed and the cavity was expanded through distraction to recreate lordosis and widen the neural foramina. The cement was then introduced into the cavity created by the corpectomies and was copiously irrigated while setting to protect against thermal injury to the spinal cord. Care was taken to avoid compromising the neural foramina during placement of the cement. Once the Al-PMMA was set, distraction was removed allowing compression against the AI-PMMA. At this point, an anterior cervical plate was placed (Medtronic, Minneapolis, MN).

\section{Post-Operative Management}

Both patients were placed on a six-week course of intravenous antibiotics specific to the etiology of their respective infections under the direction of the Infectious Disease department. One patient had cultures positive for coagulase negative staphylococcus and was placed on vancomycin; the other had positive cultures for Streptococcus oralis and was placed on ceftriaxone. Adjuvant therapy included the use of a rigid cervical collar in the patient with previous failure for 12 weeks at which time radiographs showed stable anterior and posterior cervical constructs.

\section{RESULTS}

\section{Outcome}

Both patients were evaluated postoperatively on the basis of working capacity and subjective symptoms following Odom's criteria (18) (Table I). Both had resolution of their preoperative cervical symptoms and were able to return to their normal daily activities without impairment (Odom's I). Both remain off antibiotics and have been infection free. Final postoperative $\mathrm{C}$-spine radiographs were obtained for both patients showing radiographically stable constructs without subsidence, one at 36 months and the other at 18 months postoperatively (Figures 4,5,8, 9).

\section{Complications}

The only complication that occurred was the failure of the initial iliac crest graft construct, which led to the revision

Table I: Odom's Criteria for Evaluation of Patients after Surgery on the Cervical Spine

\begin{tabular}{|c|c|}
\hline Grading & Definition \\
\hline I (excellent) & $\begin{array}{l}\text { No cervical spine symptoms, daily } \\
\text { activities not impaired }\end{array}$ \\
\hline II (good) & $\begin{array}{l}\text { Intermittent discomfort, no significant } \\
\text { interference with work }\end{array}$ \\
\hline III (fair) & $\begin{array}{l}\text { Subjective improvement, but significant } \\
\text { limitation of physical activities }\end{array}$ \\
\hline IV (poor) & $\begin{array}{l}\text { No improvement or worse compared with } \\
\text { the condition before surgery }\end{array}$ \\
\hline
\end{tabular}

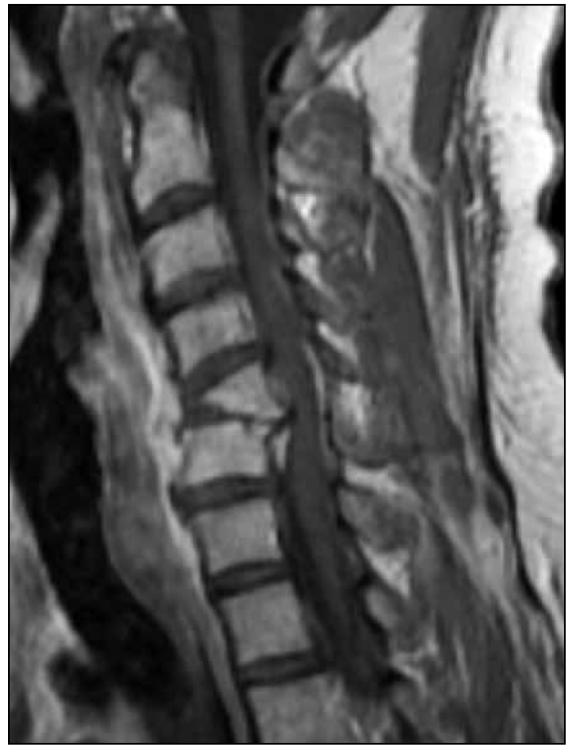

Figure 1:

Preoperative T1 weighted, contrast enhanced MRI of cervical spine. 




Figure 2: Postoperative x-ray following iliac strut placement.

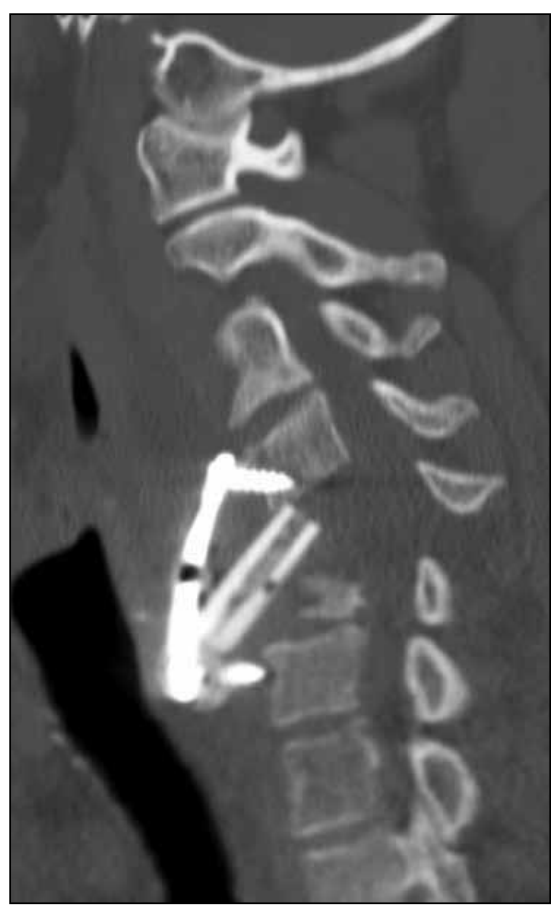

Figure 3: Failure of iliac strut graft.

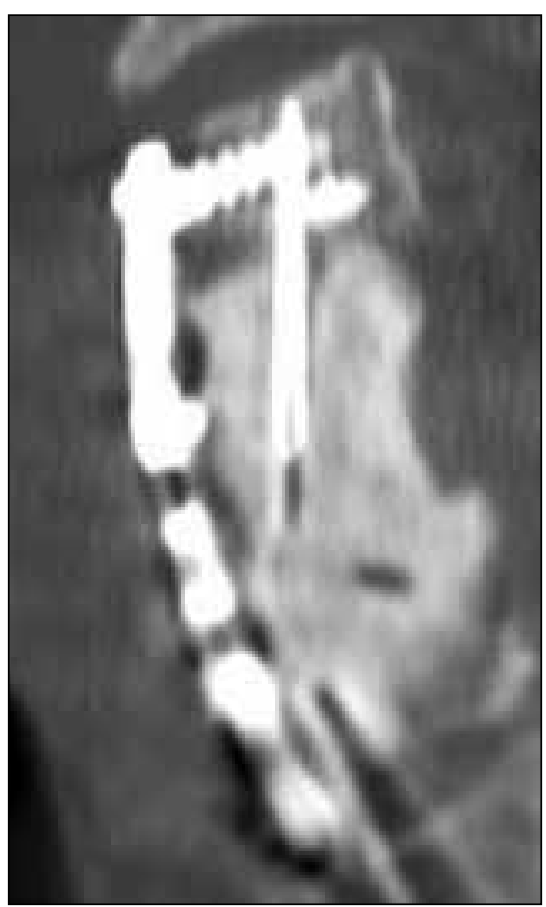

Figure 4: CT scan immediately postoperatively following reconstruction with $\mathrm{Al}-$ PMMA.

Table II: Clinical and Radiographic Indications for Surgical Treatment of Cervical Osteomyelitis

\begin{tabular}{|l|l|}
\hline Indications & Definition \\
\hline 1. Neurologic deficit & Spinal cord compression; Nerve root impingement causing weakness \\
\hline 2. Biomechanical instability & Pathologic fracture, Sagittal or coronal plane deformity \\
\hline 3. Failed conservative treatment & Intractable pain \\
\hline 4. Paravertebral or epidural abscess & Persistent infection \\
\hline
\end{tabular}

with Al-PMMA and staged posterior instrumentation. No complications from the use of AI-PMMA were encountered.

\section{DISCUSSION}

Cervical DVO with symptoms of neurologic compromise, radiographic structural instability or intolerable pain from failed medical treatment warrants surgical intervention $(1,4,7,10,11,18,22,24)$ (Table II). When reconstructing the cervical spine in cases involving pyogenic osteomyelitis, the most accepted technique is reconstruction with autologous iliac crest graft often performed in a two-step anterior procedure $(10,13,15)$. This involves an initial debridement surgery followed by placement of a rigid halo device for one week then a second debridement with subsequent fusion. Becoming more prevalent is single setting or staged 360-degree reconstruction $(13,15)$. The concerns with using autologous graft include donor site complications, lack of graft availability due to previous harvest and, as seen in one of our cases, graft dislodgement $(13,19)$. This has led to the use of various allografts including titanium, stainless steel and polyetheretherketone (PEEK) cages $(18,22)$. Allograft use for pyogenic osteomyelitis is gaining wider acceptance with studies from multiple centers refuting concerns that foreign material may lead to persistent infection and construct failure $(1,4,10,11,18,20,22,24)$. However, these implants come at an increased cost that may not be financially feasible in surgical arenas across the world. The rate for allograft implant cages range from $\$ 750$ USD to $\$ 1050$ USD compared to $\$ 300$ USD to $\$ 400$ USD for antibiotic impregnated PMMA and Steinman pins. In settings where affordability is a reality, AI-PMMA can be an effective alternative to the current industry promoted allograft implants for anterior structural support for surgical treatment of cervical osteomyelitis.

PMMA's use as a biomechanical device in anterior cervical disc decompression procedures has been well documented with stable construct rates reported between 70 and 87 percent and low complication rates $(5,6,14)$. Additionally, the successful use of beaded AI-PMMA as a temporary prophylactic measure for infected joints and long bones has been well described in the orthopedic literature $(2,3,17)$. Local antibiotic therapy has been shown to deliver high concentrations to the infected 
region with minimal detection of systemic levels. In animal models, elution is maximal the first day, greatly declines on the second day, and then gradually decreases until stabilization at 5-10 days $(9,23)$. High local concentrations are noted at 10 weeks with low serum levels; the advantage of this delivery



Figure 5: $\mathrm{CT}$

scan 18 months postoperatively. system is high local concentrations of antibiotics with no or low systemic toxicity $(9,23)$.

Our described technique using AI-PMMA for the treatment of cervical osteomyelitis is a natural translational and novel application to this knowledge. The large footprint distributes forces over possible compromised bone to increase stability and to decrease the chance of subsidence. As described in our surgical technique section, emphasis must be placed on protecting neural elements during the delivery and curing of the product $(20,21)$.

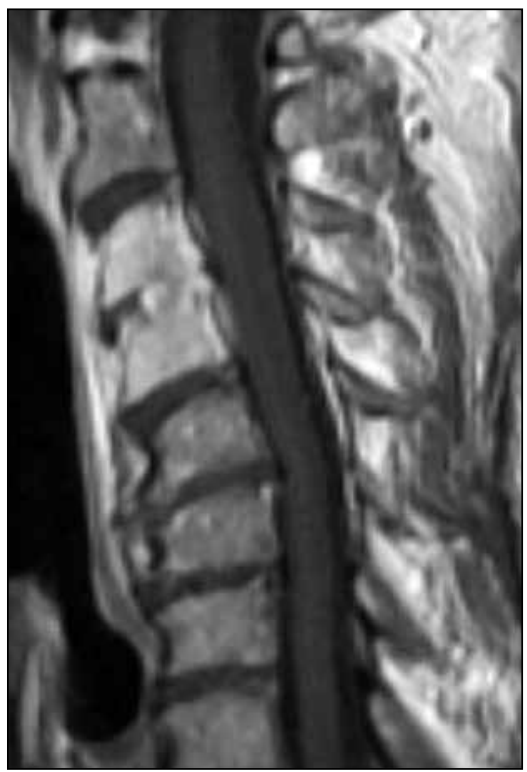

Figure 6: Preoperative T1 weighted, contrast enhanced MRI of cervical spine.

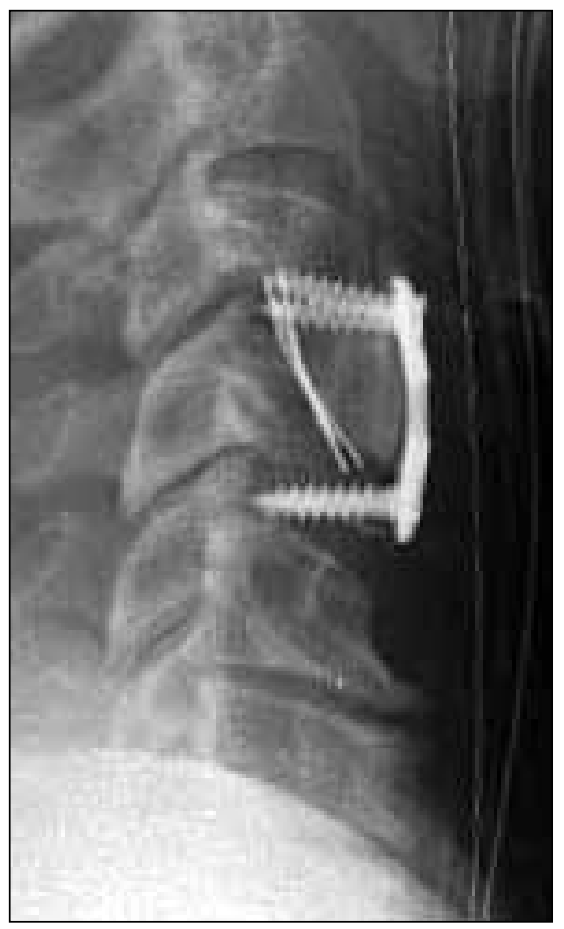

Figure 7: X-ray cervical spine immediately postoperatively.

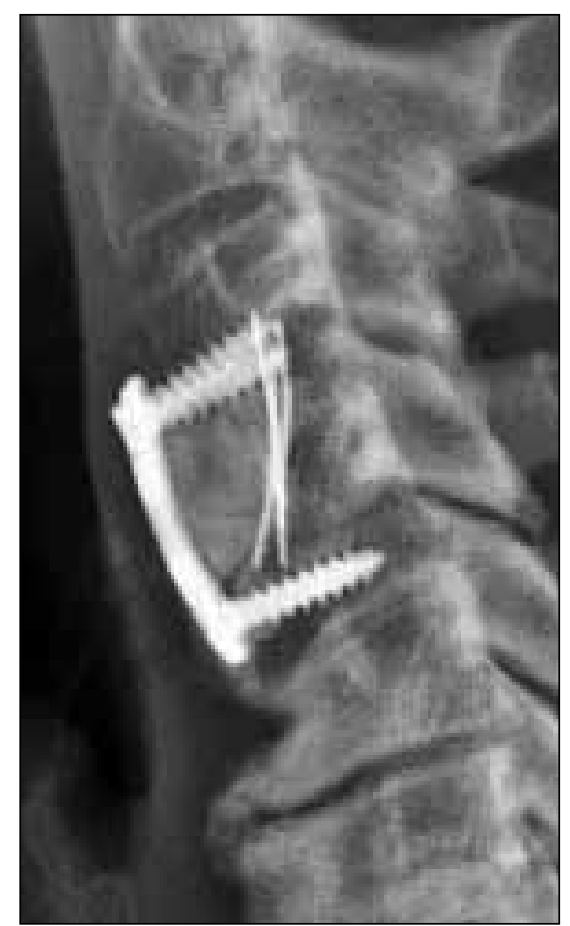

Figure 8: Extension x-ray cervical spine 36 months postoperatively.

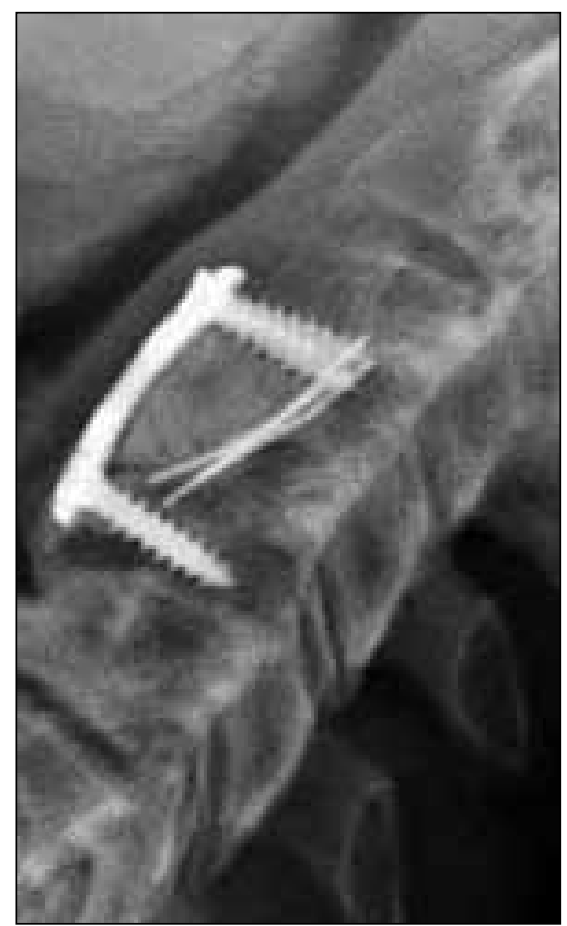

Figure 9: Flexion x-ray cervical spine 36 months postoperatively. 
The technique we describe using AI-PMMA offers immediate structural stability and local delivery of high concentration of antibiotics for less cost than other modalities. Use in these two patients has demonstrated long-term biomechanical stability and long-term infection control. The idea of a readily available, custom built biomechanical device that offers immediate stability with local delivery of antibiotics provides an appealing surgical option in the setting of DVO. Equally appealing is the potential cost savings that could be appreciated compared to the use of allograph cage implants.

\section{REFERENCES}

1. Acousta $\mathrm{FL}$, Chin $\mathrm{CT}$, Quinones-Hinojosa $\mathrm{A}$, Ames $\mathrm{CP}$, Weinstein PR, Chou D: Diagnosis and management of adult pyogenic osteomyelitis of the cervical spine. Neurosurg Focus 17(6):E2,2004

2. Buchholtz HW, Elson RA, Engelbrecht $\mathrm{E}$, Lodenkamper $\mathrm{H}_{\text {, }}$ Rottger J, Siegel A: Management of deep infection of total hip replacement. J Bone Joint Surg 63-B(3):342-353,1981

3. Cantu RC: Anterior spinal fusion using methymethacrylate (Acrylic). Int Surg 59:110-111,1974

4. Carragee $E$, lezza A: Does acute placement of instrumentation in the treatment of vertebral osteomyelitis predispose to recurrent infection: Long-term follow-up in immunesuppressed patients. Spine 33(19):2089-2093,2008

5. Chen JF, Wu CT, Lee SC, Lee, ST: Use of polymethylmethacrylate cervical cage in the treatment of single-level cervical disc disease. J Neurosurg Spine 3:24-28,2005

6. Chen $W H$, Jiang LS, Dai LY: Surgical treatment of pyogenic vertebral osteomyelitis with spinal instrumentation. Eur Spine J 16(9):1307-1316,2007

7. Currier BL: Spinal infections. In An HS (ed), Principles and Techniques of Spine Surgery. Baltimore: Williams \& Wilkins, 1998:567-603

8. Dietze DD, Fessler RG, Jacob PR: Primary reconstruction for spinal infections. J Neurosurg 86(6):981-989,1997

9. Dietze DD, Haid RW: Antibiotic-impregnated methylmethacrylate in treatment of infections with spinal instrumentation: Case report and technical note. Spine 17(8):981-987,1992

10. Dimar JR, Carreon LY, Glassman SD, Campbell MJ, Hartman MJ, Johnson JR: Treatment of pyogenic vertebral osteomyelitis with anterior debridement and fusion followed by delayed posterior spinal fusion. Spine 29(3):326-332,2004

11. Emery SE, Chan DPK, Woodward HR: Treatment of hematogenous pyogenic vertebral osteomyelitis with anterior debridement and primary bone grafting. Spine 14:284-291,1989
12. Goldstein WM, Kopplin M, Wall R, Berland K: Temporary Articulating Methylmethacrylate Antibiotic Spacer (TAMMAS). J Bone Joint Surg 83:S92-97,2001

13. Hadjipavlou AG, Mader JT, Necessary JT, Muffoletto AJ: Hematogenous pyogenic spinal infections and their surgical management. Spine 25(13):1668-1679,2000

14. Hamburger C, Festenberg FV, Uhl E: Ventral discectomy with PMMA interbody fusion for cervical disc disease. Spine 26(3):249-255,2001

15. Healey JH, Shannon F, Boland P, DiResta GR: PMMA to stabilize bone and deliver antineoplastic and antiresorptive agents. Clin Orthop Relat Res 415 Suppl:S263-275,2003

16. Hsieh PC, Wienecke RJ, O'Shaughnessy, Koski TR, Ondra SL: Surgical strategies for vertebral osteomyelitis and epidural abscess. Neurosurg Focus 17(6):E4,2004

17. Klemm K: The treatment of chronic bone infections with gentamicin-PMMA-chains and beads. In: Contzen H (ed), Gentamycin-PMMA-Kette. Vol. 20. Unfallchirurgie/Accident Surgery VLE Verlag. Verlag Erlangen, 1977:20-25

18. Lee MC, Wang MY, Fessler RG, Liawu J, Kim DH: Instrumentation in patients with spinal infection. Neurosurg Focus 17(6):E7,2004

19. Lu WW, Cheung KM, LiYW, Luk KD, Holmes AD, Zhu QA, Leong JC: Bioactive bone cement as a principal fixture for spinal burst fracture: An in vitro biomechanical and morphologic study. Spine 26(24):2684-2690,2001

20. Odom GL, Finney W: Cervical disc lesions. JAMA 166: 23-28,1958

21. Park CK, Allen MJ, Schoonmaker J, Yuan P, Bai B, Yuan HA: Gelfoam as a barrier to prevent polymethylmethacrylateinduced thermal injury of the spinal cord: In vitro and in vivo studies in pigs. J Spinal Disord 2(6):496-500,1999

22. Rayes M, Colen CB, Bahgat DA, Higashida T, Guthikonda $M$, Rengachary S, Eltahawy HA: Safety of instrumentation in patients with spinal infection. J Neurosurg Spine 12: 647-659,2010

23. Salvati EA, Callaghan JJ, Brause BD, Klein RF, Small RD: Reimplantation in infection. Elution of gentamicin from cement and beads. Clin Orthop Relat Res 207:83-93,1986

24. Seiler JG, Johnson J: Iliac crest autogenous bone grafting: Donor site complications. J South Orthop Assoc 9(2):91-97, 2000

25. Solberg BD, Gutow AP, Baumgaertner MR: Efficacy of gentamycin-impregnated resorbable hydroxyapatite cement in treating osteomyelitis in a rat model. J Orthop Trauma 13(2):102-106,1999 